\title{
The positive impact of the Airborne and Special Operations Museum on the surrounding civilian community
}

\author{
N. Suarez \& J. Bartlinski \\ Airborne and Special Operations Museum, USA
}

\begin{abstract}
Although the U.S. Army Airborne and Special Operations Museum located in downtown Fayetteville, North Carolina, is a U.S. federal institution tasked with soldier education, it has had a significant impact on the surrounding civilian community. In the past, downtown Fayetteville was known for the bars, massage parlors, and strip clubs frequented by soldiers from nearby Fort Bragg and its high crime rate. As a result, Fayetteville gained the nickname "Fayettenam" in the 1960s because it was perceived to be as dangerous as Vietnam. Since the establishment of the Airborne and Special Operations Museum in August 2000, Fayetteville has improved its reputation and become a vibrant historic and cultural hub for the region. A number of businesses, cafes, parks, museums, theatres, and other cultural institutions have emerged downtown. There have been efforts for the adaptive re-use and preservation of historic buildings and environmental clean-up in the city. Fayetteville is now known as the "All American City" due to this renaissance. The Airborne and Special Operations Museum successfully transitioned from military to civilian life by basing itself off of the military installation and within the community. The Museum is a model for other military installations wishing to foster a positive relationship with their communities.

Keywords: adaptive re-use, civilian community, environmental clean-up, historic preservation, military museum, urban renewal.
\end{abstract}

\section{Introduction}

The Airborne and Special Operations Museum (ASOM) in Fayetteville, North Carolina, facilitates a positive relationship between Fort Bragg, a U.S. Army 
installation, and the civilian community in nearby Fayetteville. Such a partnership is essential in areas where transient military populations do not invest in their civilian communities. Military installations that work with civilian community leaders have the potential to promote understanding and friendship through outreach, education, and cultural events and improve the quality of life for all. The success experienced by the ASOM can serve as an example to other military installations that experience a strain or disconnect with their civilian communities.

\section{Airborne and Special Operations Museum}

As part of the U.S. Army Center of Military History, the ASOM is a U.S. federal institution tasked with soldier education, fig. 1. According to Army Regulation 870-20, Army Art Museums, Historical Artifacts, and Art, artifacts and works of art "belong to the people of the United States, and are used to interpret the Army's history for the purpose of military training, education and research" [1]. As a side benefit, they "foster moral and esprit de corps, and contribute to informing the American people about the Army's service to the nation."

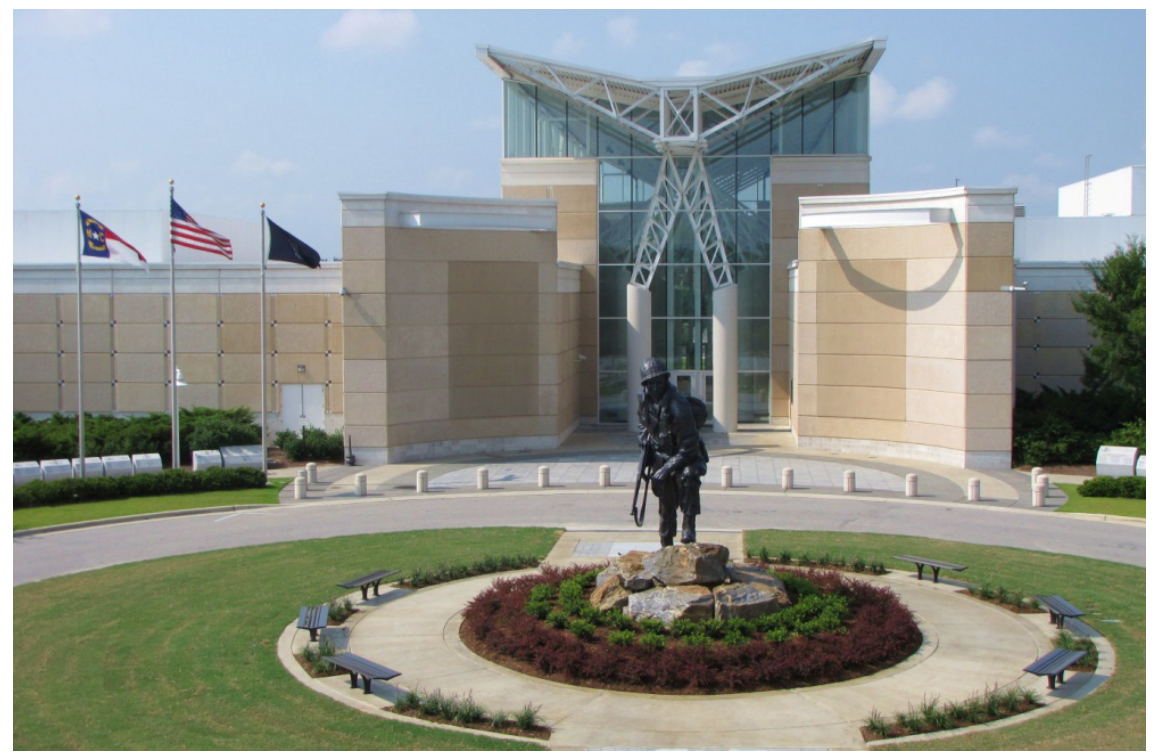

Figure 1: $\quad$ Airborne and Special Operations Museum.

ASOM, located in downtown Fayetteville, North Carolina, is a 59,000 squarefoot facility that tells the story of U.S. Army Airborne and Special Operations units. The Museum's mission is to collect, preserve, manage, and interpret artifacts pertaining to the history of U.S. parachute, glider, and special operations forces: 1940 to the present, including airborne development, Office of Strategic Services (OSS), rangers, and other special operations units. The Museum also 
serves as an adjunct to the local academic and cultural community and provides military history training to soldiers and veterans, their families, and to the public at large. In addition to the galleries, the Museum has a theatre, simulator, and gift shop.

The Museum is part of Fort Bragg, a main U.S. Army installation, located near Fayetteville. Fort Bragg contains nearly 10 percent of the Army's active forces, making it the largest U.S. Army installation by population in the world [2].

\section{3 "Fayettenam"}

Fayetteville's fate as an Army town was sealed after Fort Bragg, first known as Camp Bragg, emerged ten miles west of the city in 1918 [3]. The military had a relatively small presence in the area until World War II when thousands of soldiers came to Fort Bragg. Accordingly, Fayetteville's population began to rise and many industries relocated to the area including Black and Decker, Dupont Rohm and Hass, and Kelly-Springfield Tire Company.

Although Fayetteville grew and made progress as a result of World War II, it experienced some devastating effects during the Vietnam-era, fig. 2. Nearly 200,000 troops trained at Fort Bragg from 1966 to 1970 [4]. The surge of drug use during the 1960s, along with Fort Bragg's involvement in the Vietnam War, contributed to the rise of criminal acts in the city [5]. Both soldiers and residents

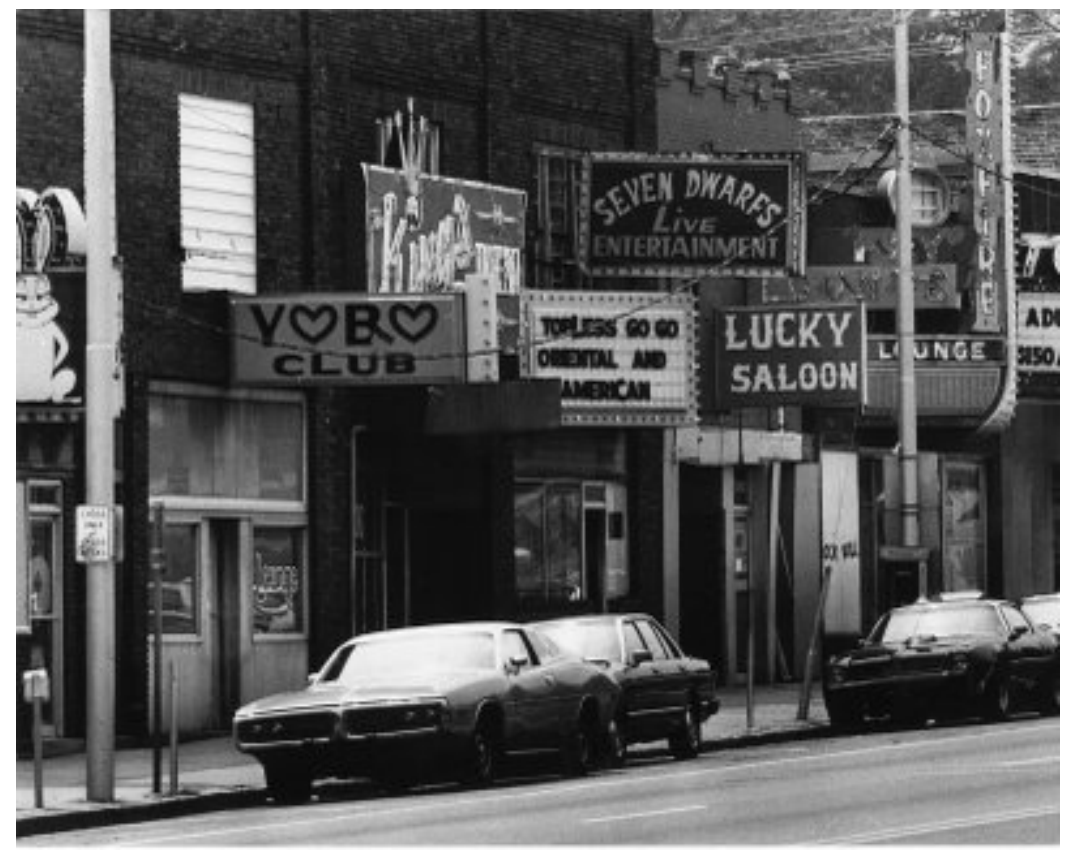

Figure 2: $\quad$ Hay Street, downtown Fayetteville in the 1970s. 
became addicts and Hay Street in downtown Fayetteville transformed from reputable businesses into a haven for immorality and debauchery. Soldiers were frequent customers at the bars, massage parlors, and strip clubs downtown. On weekends, military police were forced to patrol the area with the city police due to the high rate of crime. The city, known for its high murder rate, gained national attention and was given the nickname "Fayettenam." By the 1970s, the civilian and military communities began viewing each other with disdain and apprehension.

\section{Dispelling "Fayettenam" and downtown renewal}

Since the Vietnam War, Fayetteville mayors have made a number of unsuccessful attempts to clean up the city. Their idea of "downtown renewal" was finally realized with the conception of the ASOM in 1991. When members of the Fayetteville-Cumberland County Chamber of Commerce learned that the Airborne and Special Operations Museum Foundation (ASOMF) and the Army were attempting to build the Museum on Fort Bragg, they funded a marketing study. The study concluded that a museum such as ASOM was possible and likely to succeed in downtown Fayetteville.

In 1996, the Chamber of Commerce called a meeting with the Museum's Board of Directors, led by General (Ret.) James J. Lindsay, to propose that the Army relocate the facility to downtown Fayetteville [6]. Although ground had already been broken on Fort Bragg, the Army and the ASOMF agreed to move the Museum due to a lack of funds. The city of Fayetteville loaned millions of dollars to start the project, gave funds from its downtown revitalization project, and provided land [7].

The Museum's new location was ideal for the city of Fayetteville's desired image. In 1998, the city demolished the last of Hay Street's seedy bars for the Museum's second ground breaking. The city believed that the Museum would set the platform for Fayetteville to become a premier place and cultural destination in the region.

\section{Fayetteville's cultural renaissance: adaptive reuse, environmental cleanup, and historic preservation}

The "Fayettenam" image of the downtown area is rapidly fading, figs. 3 and 4. Fayetteville's main thoroughfare, Hay Street, has been transformed in little more than a decade from a dilapidated, seedy "red light district" to a reputable and vibrant historic district. Since the ASOM's inception in 1991, downtown Fayetteville has undergone a trendy revitalization to include coffee shops, restaurants, boutiques, art galleries, museums, community theaters, the symphony, townhomes, and condominiums. The majority of these fashionable businesses moved into the decaying and rundown historic structures that had become infamous during the City's "Fayettenam" period. The reuse of the land and historic structures linked with this cultural renaissance has resulted in a number of technical issues including environmental clean-up and preservation. 


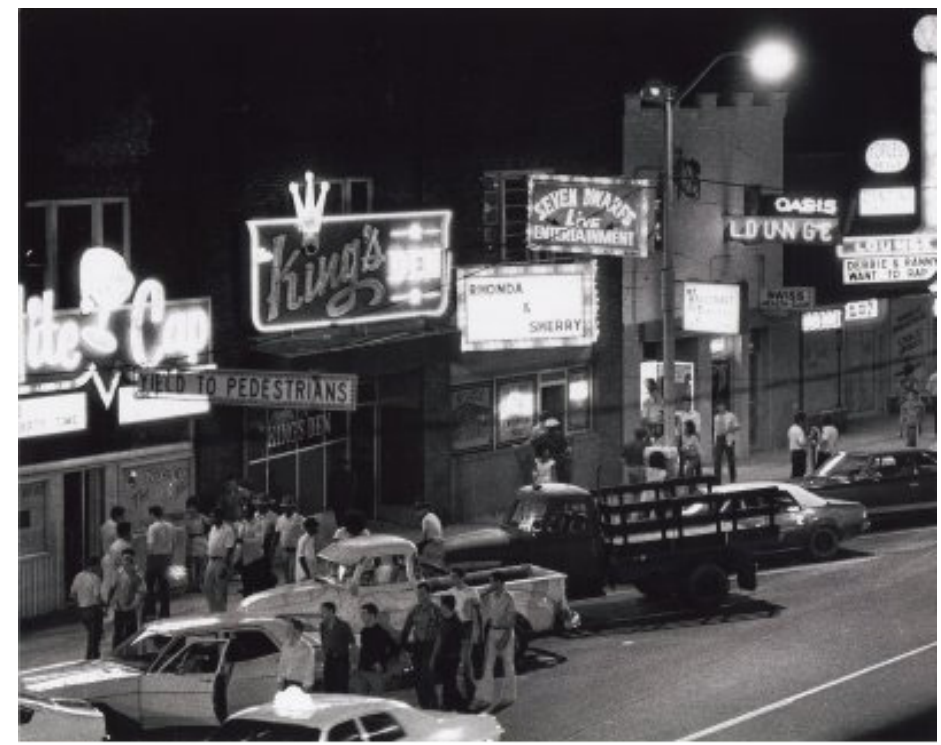

Figure 3: $\quad$ Hay Street, downtown Fayetteville, c. 1979.

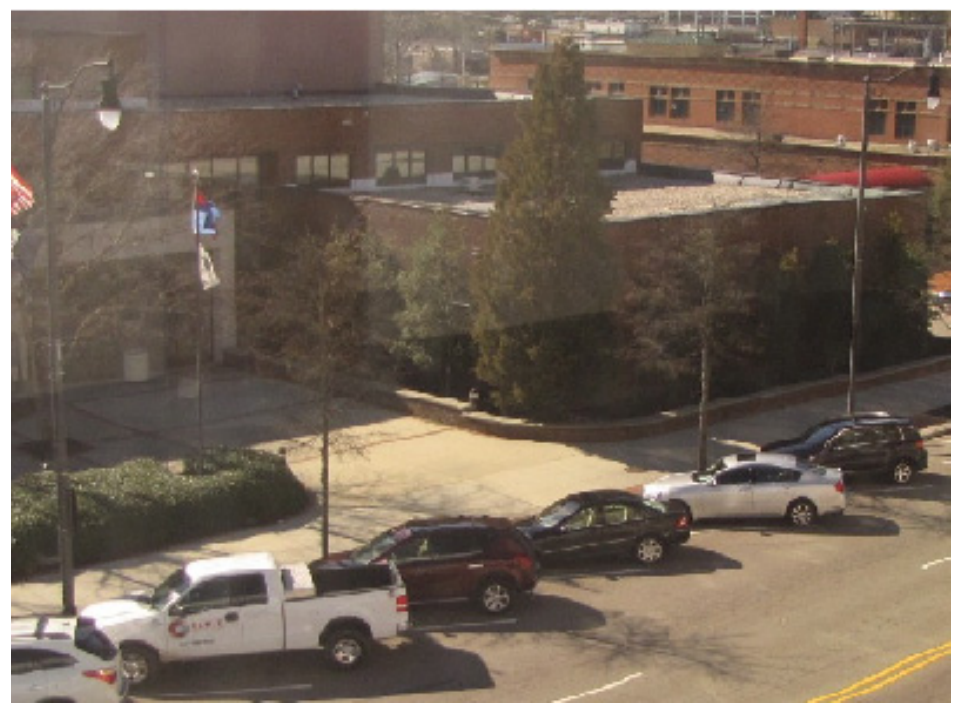

Figure 4: Hay Street, downtown Fayetteville in 2012, the former location of King's, the Seven Dwarfs, and the Oasis Lounge.

The Fayetteville Historic Resources Commission (HRC) that works in partnership with the North Carolina Historic Preservation Office (HPO) oversees thirty-five of the area's historical buildings and two historic districts. The HRC follows the National Historic Trust Main Street Model for its downtown 
revitalization, which consists of organization, promotion, design and economic restructuring [8]. The HPO provides advice to the HRC on adapted reuse and renovation projects. This is fortunate due to the fact that Fayetteville's downtown and adjacent neighborhoods are home to many exceptional examples of Neo-Classical, Gothic Revival, Romanesque Revival, and Art Deco architecture.

\subsection{Adaptive reuse}

The Fayetteville Amtrack Station, located directly next to the ASOM, is an example of adaptive reuse. Originally built as the Atlantic Coast Line Railroad in 1911, the Amtrack Station has been on the National Register of Historic Places since 1981 [9]. Of the 16 North Carolina stations served by Amtrak, Fayetteville was the sixth-busiest in 2010, boarding or detraining an average of approximately 140 passengers daily [10]. In 2005 and 2006, a restoration effort took place at the station that made it handicap accessible. Part of the station is adapted for an alternate use as a Subway sandwich shop, catering to Amtrack and museum patrons and the local community.

The City's cultural renaissance, made possible by the ASOM, also led to the adaptive reuse of many other historic properties in the downtown area. The Fayetteville Area Transportation and Local History Museum moved into the restored Cape Fear and Yadkin Valley Railroad Depot. The Railroad Depot, originally established in 1890, reopened as a museum in May of 2006 and its adjacent annex opened in June of 2010 [11]. Another museum that moved into one of Fayetteville's historical buildings is the Fascinate-U Children's Museum. As part of its revitalization effort, the City encouraged the Museum to relocate to the vacant City Hall building downtown in 1999 [12]. The structure, a building from the 1940s, had to undergo a number of upgrades prior to opening to the public. New electrical wiring and handicap accessibility measures, such as elevators and ramps, had to be installed. The Museum was also required to comply with fire regulations including fire exits and stairwells. Following the guidelines of the HRC, the Museum's façade still maintains its 1940s appearance [13].

Fayetteville is now home to a number of cultural institutions that opened downtown or relocated in that area. The CAMEO Art House Theatre opened on Hay Street in 2000 as Fayetteville's predominant venue for art films [14]. The CAMEO was once home to the New Dixie, one of Fayetteville's first motion picture theatres and later Dixie Billiards. The New Dixie opened in 1914 and nearly one hundred years later was reborn as the CAMEO after undergoing numerous renovations. There are also two live theatres, the Cape Fear Regional Theatre and the Gilbert Theater, in the downtown area. The Cape Fear is a venue for musicals, classic dramas and comedies, off-Broadway productions and children's favorites [16]. The Gilbert Theater is a performing arts venue that moved into one of Fayetteville's historic City Hall buildings in 2007 [16]. It serves as the region's creative center for showcasing local artists. The organization has invested more than $\$ 70,000$ in renovations over the last five years. 
The Arts Council and Moonlight Communications also relocated to downtown Fayetteville as a result of the ASOM. The Arts Council moved into the old United States Post Office building on Hay Street. The building is an example of the Classical Revival style, circa 1900-1924 [17]. Moonlight Communications, Inc., an award-winning, women-owned (WBE) digital media production company, relocated its business a few blocks from the ASOM. The owners saved the property dating from 1914 from demolition. After a three-year restoration process, supervised by the State Historic Preservation Office, the three-story building reopened. In 2003, Moonlight Communications, Inc. was honored with the Carraway Award for outstanding achievement in the field of historic preservation in North Carolina [18].

\subsection{Environmental cleanup}

Unfortunately for Fayetteville, some of its historic structures could not be saved and were torn down. In certain cases, the demolition of these buildings uncovered environmental issues that needed to be addressed before construction could begin. One of these projects was the ASOM, which was to be built on an unregulated commercial and industrial site. The land intended for the Museum had been occupied by the Fayetteville Observer, a daily newspaper founded in 1816, as well as a car lot, gas station, bars, and a massage parlor. The soil contamination of the land prompted the Environmental Protection Agency (EPA) to award Fayetteville a Brownfields Assessment Pilot grant of \$200,000 in 1997 to help determine the degree of contamination. After the city purchased the land to build the Museum, the ASOMF raised an additional $\$ 500,000$ to support the cleanup effort that included soil abatement and mitigation. Eventually, the land was restored to a condition safe enough to build the Museum [19].

Festival Park is another site in downtown Fayetteville where environmental cleanup efforts took place prior to construction. Festival Park, one of three parks established as a result of the revitalization program facilitated by the ASOM, is the former site of the old United Service Organization (USO) building that burned down in 2002 [20]. The USO held dances for soldiers from Fort Bragg during World War II and, at one time, was one of the biggest USOs in the world. Festival Park opened in 2006 and serves as a public venue for a variety of entertainments including firework displays and celebrations.

\subsection{Relocation of historic structures from Fort Bragg}

Fort Bragg, in partnership with the city of Fayetteville, has begun relocating historic structures in the downtown area. The Army's "Iron Mike" statue, a tribute to all Airborne soldiers, past, present and future, was dedicated on Fort Bragg in 1961. It is a 16-foot, 3,235 pound statue that depicts a World War II-era Airborne trooper holding a Thompson submachine gun in the ready position. Iron Mike stood on the military installation for forty-four years, slowly succumbing to the elements and vandals. The statue, made of fiberglass over a wire frame, underwent a 5-year restoration process undertaken with the Army, the ASOMF, and city support. It had begun to rot from the inside due to moisture 
seeping in through cracks. The straps on the statue's helmet and weapon were also broken. During the restoration process, a section of the statue was opened to let out the moisture. Cracks were filled with resin to prevent moisture. The straps on the helmet and weapon were reattached using wire and coats of resin. Iron Mike was rededicated to the Airborne soldier in August of 2010 at the ASOM. It receives yearly preservation treatments including a wax coat to prevent moisture. Today, it guards the Museum's main entrance and welcomes visitors.

Fort Bragg is also in the process of transferring ownership of a WWII barrack's mess hall and chapel to the Veterans Park. Before being turned over to the city, the Army is required to mitigate all asbestos and lead paint from the structures. Once handed over to the park, the state of North Carolina and city of Fayetteville will restore these historic structures in part to be used as museums, as well as adapting sections of the buildings for reuse as park offices and meeting venues. The transfer should take place around 2015.

\section{Educational programming and outreach within the civilian community}

ASOM's educational programming and outreach coincide with significant events in the civilian community. Likewise, the civilian community has also begun to embrace the military community through a number of military-themed events and celebrations.

Immediately adjacent to the ASOM is the North Carolina State Veterans Park. The Veterans Park opened in July of 2011. It is the first state park in the country dedicated to military veterans, both living and deceased, from all branches of the U.S. Military [21]. The Veterans Park was sited within walking distance of the ASOM to reap the benefits from the Museum's strong connections to Fort Bragg, the Airborne and Special Operations community, and the region. Visitation to the ASOM is approximately 130,000 per year, making it the venue of prominence for civic, veteran, and patriotic gatherings. ASOM opened the temporary exhibit "A Legacy of Army Service: Tarheels 1940 to Present" in conjunction with the opening of the North Carolina State Veteran's Park. Like the park, the exhibit honored veterans from North Carolina. However, the Museum stayed true to its mission by honoring North Carolinians who served with Airborne or Special Operations units.

In November of 2011, the city of Fayetteville created Heroes Homecoming as a way to honor Vietnam veterans. The ten-day commemoration culminated on Veteran's Day and offered a number of educational events, cultural celebrations, and recognition ceremonies [22]. During this time, ASOM featured a traveling Vietnam Wall and hosted lectures and movie viewings in its theatre. It also unveiled an exhibit highlighting legendary Vietnam prisoner of war James "Nick" Rowe. Due to the popularity of Heroes Homecoming, the Museum also opened the temporary exhibit “'The Animal Called POW': Special Forces Prisoners of the Vietcong" in February of 2012.

In November of 2011, the Museum fostered a partnership with the Cumberland County Education Foundation/Communities in Schools of 
Cumberland County. After receiving a grant from the Library of Congress for its Veterans History Project, leaders from the school system asked the Museum for assistance. As a result, the ASOM currently helps facilitate the project. Army staff from the Museum and Fort Bragg mentor students from the school's Junior Reserve Officers' Training Corps (ROTC) programs in oral history techniques and documentary filmmaking. Students choose military veterans from the community to interview and then conduct the interviews at the Museum under Army staff supervision. Copies of the interviews go to the Museum's archives, the veterans, the schools, and the Library of Congress.

\section{Conclusion}

The ASOM provides a tangible link and common ground for the military and civilian communities to become one. It is the catalyst for Fayetteville's downtown renaissance and reflects the local community's belief in the importance and viability of this historic part of the city [23]. The Museum continues to strengthen the relationship between the military and civilian communities by providing educational programming and outreach that is relevant to each. The ASOM is a model for other military installations wishing to foster positive relationships with their civilian populations.

\section{References}

[1] Department of the Army. Army Regulation 870-20: Army Museums, Historical Artifacts, and Art. Department of the Army, Washington D. C., p.13, 1999.

[2] An operational study of the Fayetteville Police Department: FINAL REPORT: Fayetteville Police. Police Executive Research Forum: Washington D.C. p.3, 2010.

[3] Morgan, D. T., Murder Along the Cape Fear: A North Carolina Town in the Twentieth Century, Mercer University Press: Macon, GA, pp.227-228, 2005.

[4] Military. Fort Bragg Online. http://www.globalsecurity.org/military/ facility/fort-bragg.htm

[5] Morgan, D. T., Murder Along the Cape Fear: A North Carolina Town in the Twentieth Century, Mercer University Press: Macon, GA, pp.227-228, 2005.

[6] Parker, R., Museum sets renewal state. Fayetteville Observer, p.4, August $13,2000$.

[7] Kinsler, L. Years of effort bear fruit. Fayetteville Observer. August 13, 2000.

[8] City of Fayetteville. Community Development Online. http://www.ci.fayetteville.nc.us/community development/

[9] National Register of Historic Places Web Site, http://www.nationalregisterofhistoricplaces.com/nc/state.html 
[10] Amtrak Fact Sheet, Fiscal Year 2010, State of North Carolina Online. http://www.amtrak.com/pdf/factsheets/NORTHCAROLINA10.pdf

[11] Daws, B. Personal communication, 30 January 2012, Historic Properties Manager, Fayetteville Area Transportation Museum, Fayetteville, North Carolina, USA.

[12] Daniels, S. Personal communication, 26 January 2012, Executive Director, Fascinate-U Children's Museum, Fayetteville, North Carolina, USA.

[13] Fayetteville Historic Sites, Fayetteville Area Convention \& Visitors Bureau Web Site. http://www.visitfayettevillenc.com/historicsites

[14] Kuenzel, C. Personal communication, 26 January 2012, Owner, CAMEO Art House Theater, Fayetteville, North Carolina, USA.

[15] Freedom of expression - performing arts, Fayetteville, NC Online. http://www.visitfayettevillenc.com/freedomofexpression/preformingarts.html

[16] The Gilbert Theater Web Site, http://www.gilberttheater.com/

[17] Fayetteville Historic Sites, Fayetteville Area Convention \& Visitors Bureau Web Site. http://www.visitfayettevillenc.com/historicsites

[18] Hay Street Building Renovation. Moonlight Communications Online. http://www.moonlight1.com/building.htm

[19] A salute to the armed forces in Fayetteville, U.S. Environmental Protection Agency Online. http://www.epa.gov/brownfields/success/fayetteville.pdf

[20] Fayetteville Dogwood Festival: Festival Park Online. http://www.faydogwoodfestival.com/festival-park

[21] North Carolina Veterans Park Web Site, http://www.ncveteranspark.org/

[22] Heroes Homecoming Web Site, www.heroeshomecoming.com Fayetteville, Community Development Department Web Site, Fayetteville, North Carolina, http://www.ci.fayetteville.nc.us/community development/ 